\title{
Breeding Status and Population Trends of Golden Eagles in Northeastern Québec, Canada
}

\section{Statut reproducteur et tendance de la population de l'Aigle royal dans le nord-est du Québec, Canada}

\author{
$\underline{\text { François Morneau }}^{1}$, Benoit Gagnon ${ }^{2}$, Sandie Poliquin $^{3}$, Pierre Lamothe $^{4}$, Natalie D'Astous $^{1}$ and Junior A. Tremblay $^{5}$
}

\begin{abstract}
In North America, it is hypothesized that the Golden Eagle's (Aquila chrysaetos) eastern population declined during the period 1946-1973 because of organochlorine pesticides and other anthropogenic causes of mortality. Since 1970, upward trends for the species have been observed at most eastern hawkwatches. To determine whether such positive trends can be observed on breeding grounds, Golden Eagle counts were performed to monitor nesting territory occupancy between 1994 and 2007 in the Moisie and Sainte-Marguerite River valleys, northeastern Québec. Aerial surveys were conducted during seven of the 14 years. During this period, the number of known nesting territories in the study area increased from 10 to 20, while the number of pairs rose from six to 14 . The increase is attributed mostly to investigators' improved experience in finding nests and to their greater familiarity with the study area, and possibly to the growth of the regional population. Occupancy of nesting territories by pairs was very stable over the years. Annual mean $\%$ of laying pairs (or laying rate) was $48.0(\mathrm{SD}=19.9)$, and productivity (mean number of fledglings per pair) was $0.49(\mathrm{SD}=0.35)$.
\end{abstract}

RÉSUMÉ. En Amérique du Nord, on a soulevé l'hypothèse voulant que les pesticides organochlorés et d'autres causes de mortalité d'origine anthropique aient été responsables de la diminution de la population de l'Est de l'Aigle royal (Aquila chrysaetos) au cours de la période de 1946 à 1973. Depuis 1970, des tendances à la hausse ont été observées chez cette espèce à la plupart des observatoires d'oiseaux de proie dans l'Est. Afin de déterminer si ces tendances à la hausse se reflétaient sur les lieux de reproduction, des dénombrements d'Aigles royaux ont été réalisés pour suivre l'occupation des territoires de nidification de 1994 à 2007 dans les vallées des rivières Moisie et Sainte-Marguerite, dans le nord-est du Québec. Des dénombrements aériens ont été effectués au cours de 7 des 14 années du suivi. Durant cette période, le nombre de territoires de nidification connus dans l'aire d'étude a augmenté de 10 à 20, tandis que le nombre de couples est passé de 6 à 14 . La hausse s'explique principalement par l'expérience accrue des observateurs à découvrir les nids et leur plus grande familiarité avec l'aire d'étude, et peut-être par la croissance de la population régionale. L'occupation des territoires de nidification par des couples a été très stable au cours des années. Le pourcentage annuel moyen de couples pondeurs (ou taux de ponte) s'élevait à 48,0 (écart type = 19,9) et la productivité (nombre moyen de jeunes à l'envol par couple) était de 0,49 (écart type = 0,35).

Key Words: aerial survey; Aquila chrysaetos; breeding characteristics; Golden Eagle; population trends; Québec

\section{INTRODUCTION}

In eastern North America, the Golden Eagle (Aquila chrysaetos) population is low compared with that of the western part of the continent (Katzner et al. 2012). In the early 2000s, only four pairs were known in the eastern U.S., two in Maine, and one each in Tennessee and northwestern Georgia (Kochert et al. 2002). Kirk (1996) estimated that the eastern Canadian population reached only 200-300 pairs, most of which were probably breeding in Québec and Labrador.

\footnotetext{
${ }^{1}$ Consulting Biologist, ${ }^{2}$ Environmental manager, Hydro-Québec Équipement et services partagés, ${ }^{3}$ Environmental advisor, Hydro-Québec Production, ${ }^{4}$ Retired, former Environmental advisor, Hydro-Québec Production, ${ }^{5}$ Ministère du Développement durable, de l'Environnement, de la Faune et des Parcs du Québec
}

Between 1946 and 1973, the eastern Golden Eagle population is thought to have been affected by organochlorine pesticides, reducing breeding success and consequently pair abundance (Spofford 1971, Todd 1989, Bednarz et al. 1990, Kirk 1996). This was supported by downward trends in migration counts at Hawk Mountain, Pennsylvania (Bednarz et al. 1990) and other eastern hawkwatches (Kirk 1996) and a concurrent decrease in the number of breeding pairs in the northeastern U.S. from eight (Spofford 1971) to only two (Kochert et al. 2002). Other possible causes of decline, which could be

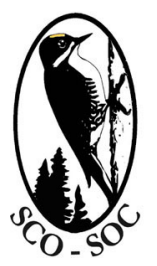

Sponsored by the Society of Canadian Ornithologists and Bird Studies Canada Parrainée par la Société des ornithologistes du Canada et Études d'oiseaux Canada

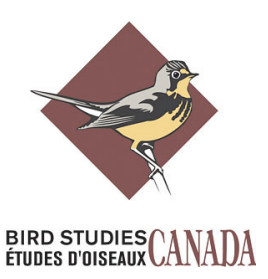


concomitant, include illegal killing, incidental trapping, secondary lead poisoning, and habitat loss resulting from increased fire protection efforts or efficiency (Spofford 1971, Singer 1974, Millsap and Vana 1984, Kirk 1996).

More recently, there is evidence suggesting that the eastern Golden Eagle population is recovering. Numbers of immature eagles at Hawk Mountain increased between 1970 and 1986 (Bednarz et al. 1990) and upward trends have also been observed more recently at some other eastern hawkwatches (Kirk 1996, Kochert and Steenhof 2002). Finally, during the period 1974-2004 and subperiods 1980-1990 and 1990-2000, increases in Golden Eagle numbers, mostly significant, were recorded in fall counts at Hawk Mountain Sanctuary and other eastern count sites (Farmer et al. 2008). However, because these trends are only known from count sites and there is no long-term nesting survey in the east, Kochert and Steenhof (2002) recommended that survey areas be developed for monitoring nesting eagles in Canada. This study presents the results of a medium term project monitoring the occupancy of nesting territories by Golden Eagles in the Moisie and SainteMarguerite River valleys in northeastern Québec. The objective was to verify if the abundance of territorial pairs increased in our study area over the focal period, as suggested by the rise of the species counts at hawkwatches in eastern North America. Because this species is designated as vulnerable in Québec and presents conservation concerns in most neighboring states and provinces (Katzner et al. 2012), it is also important to assess its breeding status in the study area.

\section{METHODS}

\section{Study area}

The study area is located north of the town of Sept-Îles, on the north shore of the Gulf of Saint-Lawrence in Québec. It consists of the Sainte-Marguerite and Moisie River valleys, from the mouths of these rivers (approximately $50^{\circ} \mathrm{N}$ ) to about $240 \mathrm{~km}$ upstream (nearly $52^{\circ} \mathrm{N}$ ). The two valleys run roughly parallel, separated by a distance of approximately $20-40 \mathrm{~km}$ (Fig. 1). The study area also includes a $126 \mathrm{~km}^{2}$ plateau overlooking the Sainte-Marguerite River valley.

Most of the region is wilderness, with human activities concentrated along the shore of the Gulf of Saint-Lawrence. However, the narrow reservoirs associated with three dams on the Sainte-Marguerite River make up a sizeable portion of the study area in terms of river length. The back country is accessible only by rail and a single road running outside the valley that links the northernmost and largest dam, the SainteMarguerite-3, on the Sainte-Marguerite River (located about $90 \mathrm{~km}$ upstream from the Gulf of Saint-Lawrence) with Highway 138 in the south (Fig. 1). The road and the dam were built between 1995 and 1998, and the Sainte-Marguerite-3 reservoir was impounded between 1998 and 2002. The railway, which runs along the southern portion of the Moisie Valley for about $22 \mathrm{~km}$, links Sept-Îles with Schefferville.
Fishing, hunting, trapping, and canoeing are the main human activities in the study area. In the mid-1990s, part of the SainteMarguerite River valley north of the Sainte-Marguerite-3 dam was clear-cut before reservoir impoundment. Clear-cutting has also occurred locally northwest of the dam, outside the reservoir (see Fig. 1).

Fig. 1. The study area and the survey area.

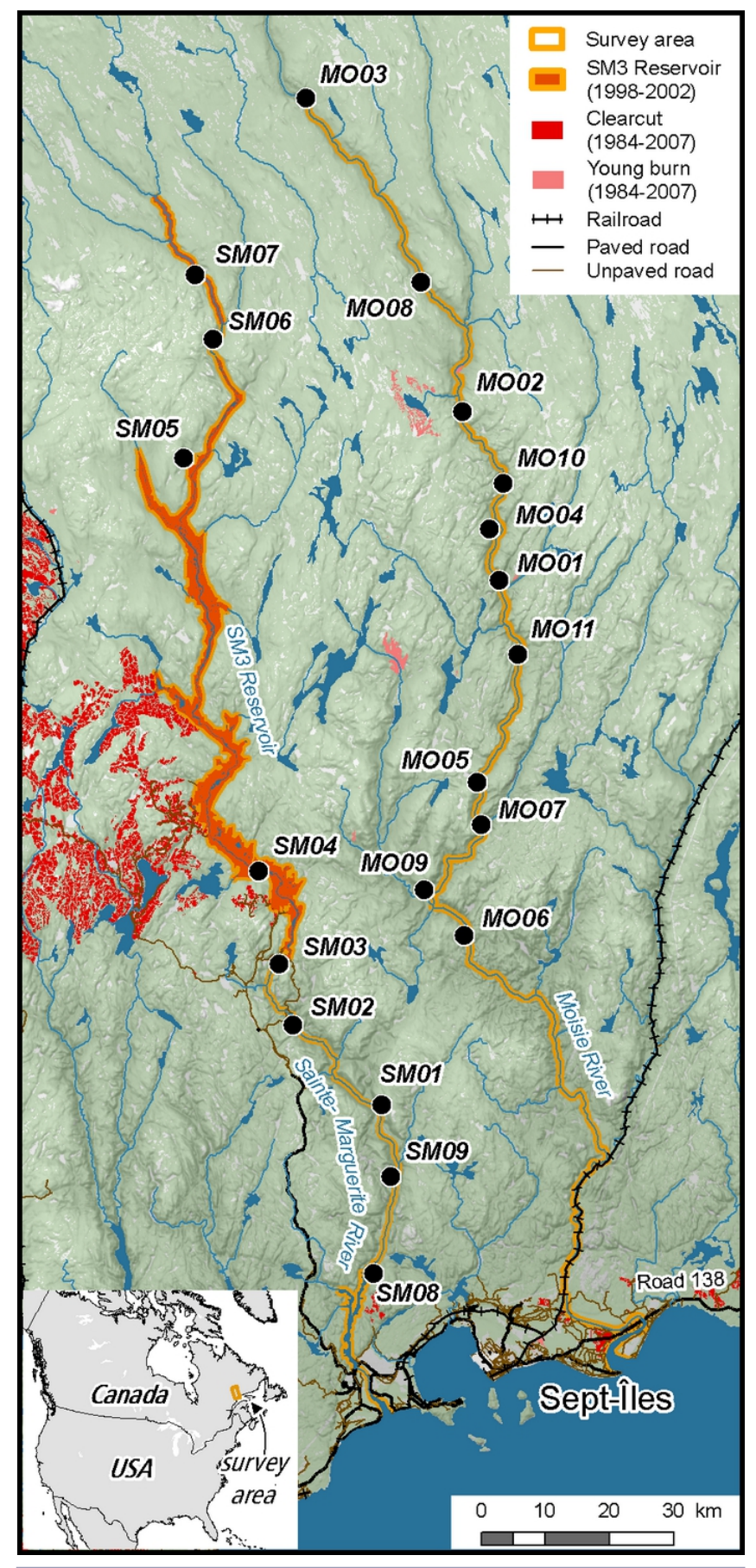


Elevations in the study area range from sea level to $1011 \mathrm{~m}$. The Moisie River valley is narrow (generally less than $2 \mathrm{~km}$ wide), U-shaped, deeply cut, and bounded by a plateau between $550 \mathrm{~m}$ and $800 \mathrm{~m}$ in elevation ( $\mathrm{Li}$ and Ducruc 1999). The Sainte-Marguerite River valley is similar, but wider (up to $6 \mathrm{~km}$ across), and U-shaped only for about one third of its length.

The study area is in the spruce-moss region. The forest canopy is dominated largely by black spruce (Picea mariana), which often occurs in pure stands but is also accompanied occasionally by other species such as balsam fir (Abies balsamea). Hardwoods comprise mostly white birch (Betula papyrifera) and trembling aspen (Populus tremuloides). The undergrowth is composed of hypnaceous mosses and ericaceous shrubs (Saucier et al. 2001). Forests cover $71 \%$ of the Sainte-Marguerite River drainage basin, with the remainder consisting of open biotopes, mainly heath $(11 \%)$, burns (10\%), and alpine tundra (6\%; Hydro-Québec, unpublished data). In the Moisie River basin, forest covers a greater proportion of the area than in the Sainte-Marguerite River basin. No major natural perturbations have occurred in the study area for at least 30 years.

\section{Terminology}

The terminology used to describe occupancy and reproductive parameters is based on recommendations from Steenhof (1987). A nesting territory is an area that contains one or more nests, including alternates ones. Nests were assigned to specific nesting territories based on their history of use by pairs of eagles and/or distance between them. Half $(4.75 \mathrm{~km})$ of the shortest distance $(9.5 \mathrm{~km})$ between the two closest nests occupied by neighboring breeding pairs in all survey years was used as a cutoff point. Any neighboring nests separated by less than that distance were assigned to the same nesting territory. Distance between closest nests of neighboring nesting territories $($ mean $=13.3 \mathrm{~km}, \mathrm{SD}=6.6 \mathrm{~km}$, range $=$ 5.9-32.8 km, $\mathrm{n}=17$ ) and distance between neighboring nests within nesting territories (mean $=1.0 \mathrm{~km}, \mathrm{SD}=1.2 \mathrm{~km}$, range $=0.0-4.6 \mathrm{~km}, \mathrm{n}=38$ ) are significantly different (MannWhitney-Wilcoxon Test, $\mathrm{W}=646, p<0.00001$ ) and show no overlap. A nesting territory was considered occupied if a territorial pair, breeding or not, or evidence of a territorial pair, i.e., incubating bird, one or more eaglets on a nest, at least one refurbished nest or greenery, was observed; otherwise it was deemed unoccupied. It was assumed that only a pair will refurbish a nest or add greenery on it. Photographs taken with a digital camera helped to identify refurbished nests (Fig. 2). A nest was so classified if the enlarged photograph showed pale tips that reveal fresh, broken twigs. It was undertaken only in the absence of other evidences of pair occupancy.

A pair of Golden Eagles that laid eggs was identified as a laying pair (Steenhof et al. 1997). It was assumed that all incubating birds had eggs. Laying rate is the annual percentage of territorial pairs that laid eggs. Nestlings that reached $\geq 51$ d of age were assumed to have fledged (Steenhof 1987). Laying pairs that produced $\geq 1$ fledgling were considered successful pairs. Productivity is the mean number of fledglings per pair and production is the total count of fledglings. Success rate is the annual percentage of laying pairs that produced at least one fledgling.

Fig. 2. Incubating Golden Eagle (Aquila chrysaetos) with new and old greenery.

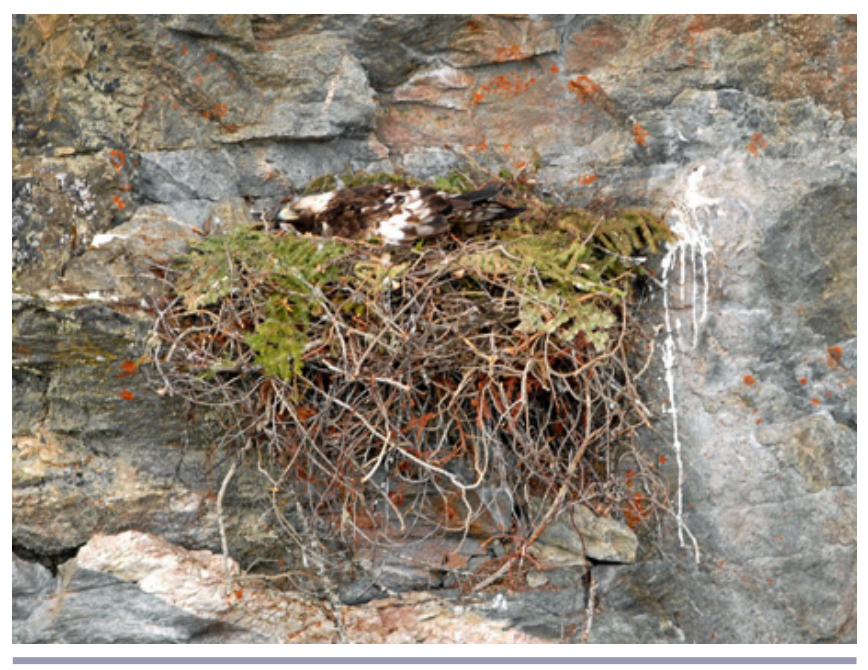

\section{Surveys}

Surveys were conducted using an A-Star 350 BA or B2 helicopter. The survey team consisted generally of three observers, two of whom participated in all surveys. The surveys focused primarily on cliffs and their immediate surroundings, although a $60 \mathrm{~km}^{2}$ mostly forested area located downstream of the Sainte-Marguerite River valley was also covered in 1997.

When the team was searching for nests, the helicopter was flown several meters below the cliff summits, 20-30 m away from the cliff face. When examining known nests, a much greater distance was maintained to minimize the disturbance to breeding eagles. Speed ranged from $10 \mathrm{~km} / \mathrm{hr}$ to $25 \mathrm{~km} / \mathrm{hr}$, but the pilot periodically hovered to give observers a better look at a nest or a particularly vegetated part of a cliff. To ensure complete coverage of the highest cliffs, two or more passes were made, beginning at the top (Kochert 1986). All flights were made under conditions of clear visibility, low winds, and above-freezing temperatures. On sunny days, for safety and accuracy reasons, we avoided examining the cliffs in the shade; westerly exposed cliffs were covered in the afternoon and easterly exposed cliffs in the morning. Once a nest was spotted, its status was determined.

Surveys were carried out twice a year, the first between midand late May to verify occupancy and to count the number of laying pairs and the second in late July to count fledglings. 
Table 1. Nesting territory occupancy by pairs of Golden Eagles (Aquila chrysaetos) in the Sainte-Marguerite and Moisie River valleys, 1994-2007 ( $\mathrm{O}$ = Occupied; $\mathrm{U}=$ Unoccupied; - = surveyed but not spotted, either because there were no nests or they were not seen; blank space $=$ not surveyed).

\begin{tabular}{|c|c|c|c|c|c|c|c|}
\hline \multirow{2}{*}{$\begin{array}{l}\text { River valley and Nesting } \\
\text { territory }\end{array}$} & \multicolumn{7}{|c|}{ Survey year } \\
\hline & 1994 & 1997 & 1998 & 2000 & 2002 & 2004 & 2007 \\
\hline \multicolumn{8}{|c|}{ Sainte-Marguerite River valley } \\
\hline SM01 & $\mathrm{O}$ & $\mathrm{O}$ & $\mathrm{O}$ & $\mathrm{O}$ & $\mathrm{O}$ & $\mathrm{O}$ & $\mathrm{O}$ \\
\hline SM02 & $\mathrm{U}$ & $\mathrm{O}$ & $\mathrm{U}$ & $\mathrm{U}$ & $\mathrm{U}$ & $\mathrm{O}$ & $\mathrm{O}$ \\
\hline SM03 & $\mathrm{U}$ & U & $\mathrm{U}$ & $\mathrm{U}$ & $\mathrm{U}$ & $\mathrm{U}$ & $\mathrm{O}$ \\
\hline SM04 & $\mathrm{U}$ & U & $\mathrm{U}$ & $\mathrm{U}$ & $\mathrm{U}$ & $\mathrm{U}$ & $\mathrm{U}$ \\
\hline SM05 & $\mathrm{U}$ & $\mathrm{U}$ & U & $\mathrm{U}$ & $\mathrm{U}$ & $\mathrm{U}$ & $\mathrm{U}$ \\
\hline SM06 & $\mathrm{O}$ & $\mathrm{O}$ & $\mathrm{O}$ & $\mathrm{O}$ & $\mathrm{O}$ & $\mathrm{O}$ & $\mathrm{O}$ \\
\hline SM07 & $\mathrm{O}$ & $\mathrm{O}$ & $\mathrm{O}$ & $\mathrm{O}$ & $\mathrm{O}$ & $\mathrm{O}$ & $\mathrm{O}$ \\
\hline SM08 & - & - & & & - & $\mathrm{U}$ & $\mathrm{U}$ \\
\hline SM09 & - & - & & & - & - & $\mathrm{O}$ \\
\hline \multicolumn{8}{|l|}{ Moisie River valley } \\
\hline MO01 & $\mathrm{O}$ & $\mathrm{O}$ & $\mathrm{O}$ & $\mathrm{O}$ & $\mathrm{O}$ & $\mathrm{U}$ & $\mathrm{O}$ \\
\hline MO02 & $\mathrm{O}$ & $\mathrm{O}$ & $\mathrm{U}$ & $\mathrm{O}$ & $\mathrm{U}$ & $\mathrm{O}$ & $\mathrm{O}$ \\
\hline MO03 & $\mathrm{O}$ & $\mathrm{O}$ & $\mathrm{O}$ & $\mathrm{O}$ & $\mathrm{O}$ & $\mathrm{O}$ & $\mathrm{O}$ \\
\hline MO04 & & U & U & $\mathrm{U}$ & $\mathrm{U}$ & $\mathrm{U}$ & $\mathrm{O}$ \\
\hline MO05 & - & - & & & $\mathrm{O}$ & $\mathrm{O}$ & $\mathrm{O}$ \\
\hline MO06 & & - & & & $\mathrm{O}$ & $\mathrm{O}$ & $\mathrm{O}$ \\
\hline MO07 & - & - & & & $\mathrm{U}$ & $\mathrm{U}$ & $\mathrm{U}$ \\
\hline MO08 & - & - & & & $\mathrm{O}$ & $\mathrm{O}$ & $\mathrm{O}$ \\
\hline MO09 & & - & & & - & $\mathrm{U}$ & $\mathrm{U}$ \\
\hline MO10 & & - & & & - & $\mathrm{U}$ & $\mathrm{U}$ \\
\hline MO11 & - & - & & & - & - & $\mathrm{O}$ \\
\hline $\begin{array}{l}\text { Total occupied nesting } \\
\text { territories }\end{array}$ & 6 & 7 & 5 & 6 & 8 & 9 & 14 \\
\hline
\end{tabular}

Vacant nesting territories found in May were examined again, sometimes at the end of the May survey, but always during the July survey. During five breeding seasons between 1994 and 2007 (1994, 1997, 2002, 2004, and 2007), all cliffs in the study area were thoroughly checked for Golden Eagle nests, except for one year (1994), when the Moisie River valley was only partially covered (40\%). During two other years (1998 and 2000), only nests of known nesting territories were monitored. The small plateau area was completely covered in all years except 1994 and 2007.

During every survey year, the following information was collected on each nesting territory covered: occupancy, nest contents (eggs and/or young), and number of eagles present. Young were aged according to Mathieu (1985) based on observations made from the helicopter. Egg-laying dates were calculated retroactively by subtracting estimated age of nestlings and $44 \mathrm{~d}$ for incubation to the observation date (Steenhof 1987).

\section{Statistical analysis}

Linear regression was used to test for trends in occupancy. Laying rate, success rate, mean productivity and occupancy rate were compared between the two valleys using t-test. The level of significance used was $\alpha=0.05$ and means are shown with SD. Statistical analyses were conducted using R software (R Development Core Team 2009).

\section{RESULTS}

From 1994 to 2007, the number of known nesting territories in the study area increased from 10 to 20 , and pair abundance rose from 6 to 14 (Table 1). In the Sainte-Marguerite River valley, the number of known pairs increased from three to six whereas, in the Moisie River valley, it more than doubled, increasing from three to eight. Three of the four nesting territories and their corresponding pairs discovered in 2002 were located in the Moisie River valley, in an area that was only being surveyed for the second or third time. In the SainteMarguerite River valley, two of the nesting territories were unoccupied during all seven survey years. Three nesting territories were occupied in 2007, but apparently not during the four or six previous survey years. In 2007, single eagles were observed in two of the unoccupied nesting territories in the Moisie River valley. In the Sainte-Marguerite River valley, no Golden Eagle nests were found either on the plateau or in the forested area. 
Table 2. Summary of reproductive characteristics of Golden Eagles (Aquila chrysaetos) in the Sainte-Marguerite and Moisie River valleys, 1994-2007.

\begin{tabular}{|c|c|c|c|c|c|c|c|}
\hline \multirow[t]{2}{*}{ Parameters } & \multicolumn{7}{|c|}{ Year } \\
\hline & 1994 & 1997 & 1998 & 2000 & 2002 & 2004 & 2007 \\
\hline $\begin{array}{l}\text { Nesting territories } \\
\text { examined }\end{array}$ & 10 & 11 & 11 & 11 & 15 & 18 & 20 \\
\hline Nesting territories occupied & 6 & 7 & 5 & 6 & 8 & 9 & 14 \\
\hline Occupancy rate $(\%)$ & 60.0 & 63.6 & 45.5 & 54.5 & 53.3 & 50.0 & 70.0 \\
\hline Pairs with eggs & 2 & 3 & 3 & 5 & 2 & 5 & 5 \\
\hline Laying rate $(\%)$ & 33.3 & 42.9 & 60.0 & 83.3 & 25.0 & 55.6 & 35.7 \\
\hline Pairs with fledglings & 1 & 2 & 3 & 5 & 2 & 5 & 4 \\
\hline Success rate $(\%)$ & 50.0 & 66.7 & 100.0 & 100.0 & 100.0 & 100.0 & 80.0 \\
\hline $\begin{array}{l}\text { Productivity } \\
\text { (mean } \pm \text { SD) }\end{array}$ & $0.17 \pm 0.37$ & $0.29 \pm 0.45$ & $0.60 \pm 0.49$ & $1.17 \pm 0.44$ & $0.25 \pm 0.43$ & $0.67 \pm 0.47$ & $0.29 \pm 0.45$ \\
\hline Production & 1 & 2 & 3 & 7 & 2 & 6 & 4 \\
\hline $\begin{array}{l}\text { Mean brood size } \\
(\text { mean } \pm \text { SD })\end{array}$ & $1.0 \pm 0.0$ & $1.0 \pm 0.0$ & $1.0 \pm 0.0$ & $1.4 \pm 0.5$ & $1.0 \pm 0.0$ & $1.2 \pm 0.4$ & $1.0 \pm 0.0$ \\
\hline
\end{tabular}

There was no trend in occupancy rate of nesting territories by territorial pairs over the years in the study area $\left(\beta_{j}=0.0035\right.$, $t$-value $\left.=0.423, r^{2}=0.0346, p=0.690\right)$. Although this relation does not present a good fit, occupancy rate trends of the two valleys had significantly different slopes $(F=5.5556, d f=13$, $p=0.0402$ ), and mean annual occupancy rate between both valleys (MO: $69.3 \pm 17.4 \%$ vs SM: $53.4 \pm 8.7 \%$ ) was not significantly different $(t=2.1687, d f=8.82, p=0.0588)$. Mean annual occupancy rate for the study area was $56.7 \% \pm 8.4 \%$. All nesting territories occupied in 1994 were still occupied in 2007 (Table 1). Nesting territories that were occupied when discovered or vacant ones that subsequently became occupied remained, with few exceptions, occupied for the remainder of the survey years. Interestingly, in the second category, with only one exception, occupied nests that were found after a year of no occupancy appeared to be refurbished former nests. Furthermore, one nesting territory (\#SM02), located in the Sainte-Marguerite River valley, was apparently abandoned in 1997 and not used again until 2003 or 2004.

Nests were discovered in every survey year but 2000. Most of them were probably former nests and assigned to known nesting territories. In 2007, in the last survey year, the mean number of known nests/nesting territory was 3.3 ( $\mathrm{SD}=2.2$ nests/nesting territory, range 1-8) for a total of 65 nests. All were located on cliffs, on a mean of 2.3 nesting cliffs/nesting territories ( $\mathrm{SD}=1.4$ nesting cliff/nesting territory, range 1-6). The back-calculated laying period revealed that the May aerial surveys were conducted at the end of the incubation period.

Annual mean laying rate in the study area (percentage of territorial pairs that laid eggs) was $48.0 \pm 19.9 \%$ (no difference between valleys, $t=0.1902, d f=10.36, p=0.8528$ ), while annual mean productivity was $0.49 \pm 0.35$ (no difference between valleys, $t=-0.7184, d f=10.21, p=0.4886$ ) (Table 2). Two nests contained two fledglings each in 2000 and one nest in 2004. Annual mean success rate was $85.2 \% \pm 20.3 \%$ (no difference between valleys, $t=-0.8341, d f=11.46, p=$ 0.4213).

\section{DISCUSSION}

In the study area, the number of known nesting territories occupied by pairs of Golden Eagles increased between 1994 and 2007 as has the total number of known nesting territories. This situation occurred in both valleys. Occupancy rate of nesting territories was relatively stable over the years and did not differ significantly between the two valleys. About half of the pairs seemed to lay eggs in an average year but with high success rates.

Prior to our study, breeding evidence had never been secured for the species in the region (Robert 1996). Todd (1963) reported a supposed Bald Eagle (Haliaeetus leucocephalus) nest on a cliff along the Sainte-Marguerite River that was pointed out to him by his Innu guides during his canoe journey from the Gulf of Saint-Lawrence to Ungava Bay in 1917. However, the Bald Eagle is not known to nest on cliffs in the province (Ministère du Développement durable, de l'Environnement, de la Faune et des Parcs du Québec [MDDEFP], unpublished data). Furthermore, the coordinates that Todd provided correspond to a cliff that, during our study, contained three Golden Eagle nests and where breeding of this species occurred. Clearly, Golden Eagles have most probably been breeding in the study area for a long time.

Our aerial censuses appear to be accurate. According to Kochert (1986), occupancy surveys are more accurate after clutches have been completed, but before the first eggs hatch. Based on the estimated breeding chronology, this timing was achieved during all survey years. The area covered was exactly the same during every complete survey year except the first, which also increased survey accuracy. 
We attribute the increase in the number of Golden Eagle pairs and nesting territories observed between 1994 and 2007 mainly to our greater experience and familiarity with the study area. It generally takes two or more survey years to completely identify all nesting territories and territorial pairs in an area (Phillips and Beske 1990, McIntyre and Adams 1999). This factor explains most if not all of the discoveries made in 2002, which occurred in a sector of the Moisie River valley that was being covered only for the second or third time. Furthermore, the two valleys surveyed have numerous cliffs, several exceeding $200 \mathrm{~m}$ in height, with the highest reaching $330 \mathrm{~m}$, and the longest over $1 \mathrm{~km}$ in length, making it very difficult to locate nests. As an example of greater experience, the first survey year, we observed that there was a streak of nitrophilous lichen of variable length on the rock face under the ledge of the majority of nests. This clue helped to find some nests in subsequent years. Several unused nests were covered by grassy and/or shrubby vegetation. After we became aware of this situation, some of these nests were found over the survey years by positioning the helicopter at different angles to potential nests or when they became used by a pair of eagles.

Nevertheless, a possible increase of pair abundance cannot be ruled out between 2002 and 2007. In the latest year, three pairs were identified for the first time in areas being surveyed for the fifth or seventh times. As an indication, an increase in Golden Eagle numbers was recorded at most eastern hawkwatches during 1974-2004. For example, at Hawk Mountain Sanctuary, Pennsylvania, there was a significant average percentage of change of $2.1 \pm 1.3$ Golden Eagles annually (average annual total count $=72$ Golden Eagles; Farmer et al. 2008). The only exception worthy of note is the Observatoire d'oiseaux de Tadoussac (Tadoussac bird observatory), located about $500 \mathrm{~km}$ southwest of the study area, where no trends were observed during the period 1990-2000. The absence of trends at Tadoussac can probably be partly explained by the high percentage of juvenile birds in the fall count most years (75\% in 2007; Côté 2007). Indeed, juvenile Golden Eagle productivity in northern areas is highly variable from year to year, as noted in Denali National Park, Alaska (McIntyre and Adams 1999), in Sweden (Moss et al. 2012), and in this study. There are also indications that the number of Golden Eagles shot annually in the province has dropped in the last decade or so. Indeed, between 1991 and 2007, the percentage of birds of prey shot, admitted for rehabilitation, or found dead decreased significantly from $13.4 \%$ to $2.2 \%$ ( $81 \mathrm{birds}$ shot/year to $23 \mathrm{birds}$ shot/year; Desmarchelier et al. 2010). However, it is important to underline that it does not account for other causes of death such as incidental trapping and poisoning. Obviously, one or more surveys are needed in the study area to clarify population trends.

The fact that occupied nesting territories had generally remained at this state over the years indicates at least a stable population. Moreover, occupancy of a few nesting territories might have been overlooked some years in previously occupied areas, as suggested by the nests found after a year of apparent vacancy. Mean occupancy percentage (56.7\%) was lower than that observed by McIntyre (2002) in Denali National Park, Alaska, where $75 \%$ of nesting territories monitored for $\geq 10 \mathrm{yr}$ were occupied all years. The difference may be partly explained by the stability and area of open biotopes that are potential hunting habitats for the Golden Eagle. In Alaska, most (88.9\%) of the area within $3000 \mathrm{~m}$ territory cores around nests is in the alpine zone and consists of open permanent habitats (McIntyre et al. 2006). In the study area, in contrast, most of open biotopes are heath and burns that tend to disappear with forest succession. Nesting territories that were unoccupied all seven survey years are surrounded by mature forest and contained nests in poor conditions (F. Morneau, unpublished data). These territories are probably abandoned. Low cover of open biotopes could also explain that other nesting territories were unoccupied during survey years. In Scotland and in the Alps, afforestation and land abandonment are causing forest expansion that affects Golden Eagle productivity and probably territory occupancy (Marquiss et al. 1985, Watson 1992, Pedrini and Sergio 2001a). In the Adirondacks, forest fire suppression is thought to be one of the main causes of the species' decline in the last century by reducing the extent of burns owing to forest succession (Singer 1974).

Laying rates obtained in this study are somewhat lower than values observed in Idaho (annual mean $=70.0 \pm 15.5 \%$; Steenhof et al. 1997) and Denali National Park, Alaska (annual mean $=62.1 \pm 19.5 \%$; McIntyre and Adams 1999). These investigators also found large annual variations in this parameter. A possible cause of underestimation is nesting failure prior to the May survey, making nests that had been occupied look unoccupied when we checked them. However, this factor is probably marginal because no bowls were found within vacant nests, a shape typical of nests that are used for nesting (Kochert et al. 2002). Low laying rates could also partly be due to the fact that some territorial pairs could have been composed of at least one subadult bird. Such pairs have a lower laying rate than those consisting of adult birds only (Sánchez-Zapata et al. 2000). Subadult birds maintain breeding territories when the population is increasing or when adult numbers become depleted (Bergo 1984, Sánchez-Zapata et al. 2000). Finally, one or more year with high laying rate could have been missed because survey years were not always consecutive.

The mean annual productivity obtained ( 0.49 fledgling/pair) is lower than values observed in several western regions of the continent and in Scotland (0.78-1.08 fledgling/pair; Kochert et al. 2002). However, it is within the range observed in the Alps (0.29-0.95 fledgling/pair; Pedrini and Sergio $2001 b$ ) and close to the values observed in Denali National 
Park, Alaska (0.66 fledgling/pair; McIntyre and Adams 1999), in Sweden (0.64 fledgling/pair; Tjernberg 1983; and 0.68 fledgling/pair; Moss et al. 2012), and in the Northwest Territories, Canada (0.63 fledgling/pair; Poole and Bromley 1988). McIntyre and Adams (1999) observed that Golden Eagles in northern areas had smaller broods and produced fewer fledglings than their counterparts in more temperate areas. They hypothesized that this lower productivity may result from the energetic costs associated with migration combined with low prey diversity on the breeding grounds. Golden Eagles are probably migratory in the study area because the Hudson Bay population in the province is migratory (Brodeur et al. 1996), as is the population on the Gaspé Peninsula (MDDEFP, unpublished data). The low reproductive rate is obviously a product of the low egg laying rate because reproductive success was high during most survey years. It is also possible that one or more highly productive years in the study period were missed because surveys were not carried out in successive years. A single year with productivity as high as that in 2000 would increase the mean ratio of fledglings per pair to 0.59 .

Golden Eagle is designated as vulnerable in the province and presents a similar status in most neighboring states and provinces (Katzner et al. 2012). Its population in eastern North America probably reaches only a few hundred pairs and indicators at eastern hawkwatches suggest upward trends. However, knowledge on demography is still lacking. Although this study provides some insight, annual breeding monitoring is needed to evaluate long-term trends and variability in reproductive characteristics of this population. Therefore, we recommend Sainte-Marguerite and Moisie River valleys as a study area for future monitoring.

Responses to this article can be read online at: http://www.ace-eco.org/issues/responses.php/547

\section{Acknowledgments:}

This study was part of the impact studies and monitoring program undertaken by Hydro-Québec for the SainteMarguerite-3 hydroelectric project, as well as the five-year Golden Eagle survey coordinated by the Ministère des Ressources naturelles et de la Faune du Québec (MRNF). We wish to thank Alain Lanoue, Serge Brodeur, and Martin Picard for their contributions to the field work. Grant Gilchrist, Keith Hobson, Betsy McFarlane, D. Ryan Norris, Marc-André Villard, and six anonymous reviewers helped to improve this manuscript through many constructive comments.

\section{LITERATURE CITED}

Bednarz, J. C., D. Klem, Jr., L. J. Goodrich, and S. E. Senner. 1990. Migration counts of raptors at Hawk Mountain, Pennsylvania, as indicators of population trends, 1934-1986. Auk 107:96-109.

Bergo, G. 1984. Population size, spacing and age structure of Golden Eagle Aquila chrysaetos (L.) in Hordaland, West Norway. Fauna Norvegica-Series C. Cinclus 7:106-108.

Brodeur, S., R. Décarie, D. M. Bird, and M. Fuller. 1996. Complete migration cycle of Golden Eagles breeding in northern Quebec. Condor 98:293-299. http://dx.doi. org $/ 10.2307 / 1369147$

Côté, P. 2007. Rapport d'activité de la saison 2007. Observatoire d'oiseaux de Tadoussac, Explos-Nature, Les Bergeronnes, Québec, Canada.

Desmarchelier, M., A. Santamaria-Bouvier, G. Fitzgérald, and S. Lair. 2010. Mortality and morbidity associated with gunshots in raptorial birds from the province of Quebec: 1986 to 2007. Canadian Veterinary Journal 51:70-74.

Farmer, C. J., R. J. Bell, B. Drolet, L. J. Goodrich, E. Greenstone, D. Grove, D. J. T. Hussell, D. Mizrahi, F. J. Nicoletti, and J. Sodergren. 2008. Trends in autumn counts of migratory raptors in northeastern North America, 1974-2004. Pages 179-215 in K. L. Bildstein, J. P. Smith, E. Ruelas Inzunza, and R. R. Veit, editors. State of North America's birds of prey. Series in Ornithology No. 3. Nuttall Ornithological Club, Cambridge, Massachusetts, and American Ornithologists' Union, Washington, D.C., USA

Katzner, T., B. W. Smith, T. A. Miller, D. Brandes, J. Cooper, M. Lanzone, D. Brauning, C. Farmer, S. Harding, D. E. Kramar, C. Koppie, C. Maisonneuve, M. Martell, E. K. Mojica, C. Todd, J. A. Tremblay, M. Wheeler, D. F. Brinker, T. E. Chubbs, R. Gubler, K. O'Malley, S. Mehus, B. Porter, R. P. Brooks, B. D. Watts, and K. L. Bildstein. 2012. Status, biology, and conservation priorities for North America's eastern Golden Eagle (Aquila chrysaetos) population. Auk 129:168-176. http://dx.doi.org/10.1525/auk.2011.11078

Kirk, D. A. 1996. Updated status report on the Golden Eagle Aquila chrysaetos in Canada. Committee on the Status of Endangered Wildlife in Canada, Ottawa, Ontario, Canada.

Kochert, M. N. 1986. Raptors. Pages 313-349 in A. L. Cooperrider, R. J. Boyd, and H. R. Stuart, editors. Inventory and monitoring of wildlife habitat. United States Department of Interior, Bureau of Land Management, Service Center, Denver, Colorado, USA.

Kochert, M. N., K. Steenhof, C. L. McIntyre, and E. H. Craig. 2002. Golden Eagle (Aquila chrysaetos). In A. Poole and F. Gill, editors. Birds of North America, Number 684. Academy 
of Natural Sciences, Philadelphia, Pennsylvania, USA, and American Ornithologists' Union, Washington, D.C., USA. [online] URL: http://bna.birds.cornell.edu/bna/species/684/ articles/introduction

Kochert, M. N., and K. Steenhof. 2002. Golden Eagles in the U.S. and Canada: status, trends, and conservation challenges. Journal of Raptor Research 36(1 Supplement):32-40.

Li, T., and J. P. Ducruc. 1999. Les provinces naturelles. Niveau I du cadre écologique de référence du Québec. Ministère de l'Environnement, Québec, Québec, Canada.

Marquiss, M., D. A. Ratcliffe, and R. Roxburgh. 1985. The numbers, breeding success and diet of Golden Eagles in southern Scotland in relation to changes in land use. Biological Conservation 34:121-140. http://dx.doi.org/10.1016/0006-3207 (85)90104-1

McIntyre, C. L. 2002. Patterns in nesting area occupancy and reproductive success of Golden Eagles (Aquila chrysaetos) in Denali National Park and Preserve, Alaska. 1988-99. Journal of Raptor Research 36(1 supplement):50-54.

McIntyre, C. L., and L. G. Adams. 1999. Reproductive characteristics of migratory Golden Eagles in Denali National Park, Alaska. Condor 101:115-123. http://dx.doi.org/10.2307/1370452

McIntyre, C. L., M. W. Collopy, J. G. Kidd, A. A. Stickney, and J. Paynter. 2006. Characteristics of the landscape surrounding Golden Eagle nest sites in Denali National Park and Preserve, Alaska. Journal of Raptor Research 40:46-51. http://dx.doi.org/10.3356/0892-1016(2006)40[46:COTLSG]2.0. $\mathrm{CO} ; 2$

Mathieu, R. 1985. Développement du poussin d'Aigle royal (Aquila chrysaetos) et détermination de l'âge dans la nature par l'observation éloignée. Bièvre 7:71-86.

Millsap, B. A., and S. L. Vana. 1984. Distribution of wintering Golden Eagles in the eastern United States. Wilson Bulletin 96:692-701.

Moss, E. H. R., T. Hipkiss, I. Oskarsson, A. Häger, T. Eriksson, L.-E. Nilsson, S. Halling, P.-O. Nilsson, and B. Hörnfeldt. 2012. Long-term study of reproductive performance in Golden Eagles in relation to food supply in boreal Sweden. Journal of Raptor Research 46:248-257. http://dx.doi.org/10.3356/ JRR-11-48.1

Pedrini, P., and F. Sergio. 2001a. Golden Eagle Aquila chrysaetos density and productivity in relation to land abandonment and forest expansion in the Alps. Bird study 48:194-199. http://dx.doi.org/10.1080/00063650109461218

Pedrini, P., and F. Sergio. 2001b. Density, productivity, diet, and human persecution of Golden Eagles (Aquila chrysaetos) in the central-eastern Italian Alps. Journal of Raptor Research 35:40-48.
Phillips, R. L., and A. E. Beske. 1990. Distribution and abundance of Golden Eagles and other raptors in Campbell and Converse Counties, Wyoming. United States Department of the Interior, Fish and Wildlife Technical Report, No. 27. Washington, D.C., USA.

Poole, K. G., and R. G. Bromley. 1988. Interrelationships within a raptor guild in the central Canadian Arctic. Canadian Journal of Zoology 66:2275-2282. http://dx.doi.org/10.1139/ $\underline{\text { z88-338 }}$

$\mathrm{R}$ Development Core Team. 2009. R: a language and environment for statistical computing. Reference index version 2.10.1. R Foundation for Statistical Computing, Vienna, Austria. ISBN 3-900051-07-0. [online] URL: http:// www.R-project.org

Robert, M. 1996. Golden Eagle. Pages 396-399 in J. Gauthier and Y. Aubry, editors. The breeding birds of Quebec: atlas of the breeding birds of southern Quebec. Canadian Wildlife Service, Sainte-Foy, Quebec, Canada.

Sánchez-Zapata, J. A., J. F. Calvo, M. Carrete, and J. E. Martínez. 2000. Age and breeding success of a Golden Eagle Aquila chrysaetos population in southeastern Spain. Bird Study 47:235-237. http://dx.doi.org/10.1080/00063650009461179

Saucier, J. P., P. Grondin, A. Robitaille, and J. F. Bergeron. 2001. Zones de végétation et domaines bioclimatiques $d u$ Québec ( $3^{\text {ème }}$ version). Direction des inventaires forestiers, ministère des Ressources naturelles du Québec, Québec, Canada.

Singer, F. J. 1974. Status of the Osprey, Bald Eagle, and Golden Eagle in the Adirondacks. New York Fish and Game Journal 21:18-31.

Spofford, W. R. 1971. The breeding status of the Golden Eagle in the Appalachians. American Birds 25:3-7.

Steenhof, K. 1987. Assessing raptor reproductive success and productivity. Pages 157-170 in B. A. Giron Pendleton, B. A. Millsap, K. W. Cline, and D. M. Bird, editors. Raptor Management Techniques Manual. National Wildlife Federation, Washington, D.C., USA.

Steenhof, K., M. N. Kochert, and T. L. McDonald. 1997. Interactive effects of prey and weather on Golden Eagle reproduction. Journal of Animal Ecology 66:350-362. http:// dx.doi.org/10.2307/5981

Tjernberg, M. 1983. Prey abundance and reproductive success of the Golden Eagle (Aquila chrysaetos) in Sweden. Holarctic Ecology 6:17-23.

Todd, C.S. 1989. Golden Eagle. Pages 65-70 in Proceedings of the Northeast Raptor Management Symposium and Workshop. Syracuse, New York. National Wildlife Federation, Washington, D.C., USA. 
Todd, W. W. C. 1963. Birds of the Labrador Peninsula and adjacent areas. A distributional list. University of Toronto Press, Toronto, Ontario, Canada.

Watson, J. 1992. Golden Eagle Aquila chrysaetos breeding success and afforestation in Argyll. Bird Study 39:203-206.

http://dx.doi.org/10.1080/00063659209477120 